\title{
Publisher Correction to: Comparing apples and pears: misleading conclusions about the population mental health impact of a parenting programme, a commentary on Marryat, Thompson and Wilson (2017)
}

BMC Pediatrics

Publisher Correction to: BMC Pediatr https://doi.org/10.1186/

s12887-019-1570-z

The original version of this article [1] was published in error before the text of the article had been finalised. The article has now been corrected. The publisher apologizes for the inconvenience caused to the authors and readers.

Published online: 15 October 2019

\section{Reference}

1. Sanders MR, de Caestecker L, McLeod S, et al. Comparing apples and pears: misleading conclusions about the population mental health impact of a parenting programme, a commentary on Marryat, Thompson and Wilson (2017). BMC Pediatr. 2019;19:269 https://doi.org/10.1186/s12887-019-1570-z. 